\title{
Evaluating the Replacement of Galvanic Cr Coatings
}

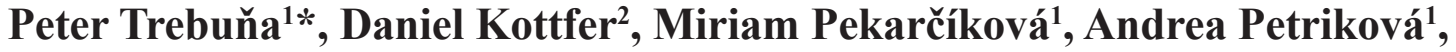 \\ Radko Popovičํ, František Rehák ${ }^{3}$, Peter Čižnár ${ }^{4}$
}

\author{
${ }^{1}$ Technical University of Košice, Faculty of Mechanical Engineering, Institute of Management, Industrial and Digital \\ Engineering, Park Komenského 9, 04200 Košice, Slovak Republic \\ ${ }^{2}$ Technical University of Košice, Faculty of Mechanical Engineering, Department of Mechanical Technologies \\ and Materials, Mäsiarska 74, 04001 Košice, Slovak Republic \\ ${ }^{3}$ Alexander Dubček University of Trenčín, Faculty of Industrial Technologies, \\ I. Krasku 491/30, 02001 Púchov, Slovak Republic \\ ${ }^{4}$ Nuclear and Decommissioning Company, Bratislava, Slovakia
}

Received: 10 April 2017

Accepted: 26 August 2017

\begin{abstract}
Our paper deals with the possibility of replacing galvanic chrome coatings with thermal spraying, specifically with the high-velocity oxy-fuel coating spraying (HVOF) method. The article provides an analysis of alternatives compensation, mutual comparison of thermal spraying methods, and the choice of the most appropriate method for replacing galvanic chrome plating. Increased pressure on health and the environment necessitates the replacement of conventional galvanic plating process solution with hexavalent chromium $\mathrm{Cr}^{6+}$ by using environmentally friendly technology.
\end{abstract}

Keywords: galvanic, chrome, coating, method, environment

\section{Introduction}

Excellent resistance to wear and corrosion predetermine galvanically deposited chromium coatings for utilizatio in the automotive and aerospace industries [1-4]. The disadvantage of this technology is creation of thickness that is not uniform (Table 1). Their positive features include particularly high adhesion to the steel surface, and a hardness of $8 \mathrm{GPa}$ at room temperature and above $4 \mathrm{GPa}$ after ignition at temperatures of up to $600^{\circ} \mathrm{C}$. Technology of Hard Chrome is typically used to protect the surface against abrasive wear and to the

*e-mail: miriam.pekarcikova@tuke.sk recovery of worn surfaces, original dimensions, and shape. These conventional electroplated chrome layers formed from an electrolyte with hexavalent chromium have been used for 120 years. However, over the last decade there has been increased pressure on health and the environment. One of the acceptable solutions was proposed replacement of the conventional process of galvanic plating solution to hexavalent chromium $\mathrm{Cr}^{6+}$ for environmental technologies. One of the most acceptable ecological options is electro-plating using a trivalent chromium electrolyte, thermal spraying, chemical vapour deposition (CVD), or physical vapour deposition (PVD). We examined coatings composed of several elements deposited alloy multiple combinations of elements such as Cr-C, Ni-Mo [6-7], Ni-Co [2, 5, 8-9] and Ni-Mo-Co 
Table 1. Maximum thickness of galvanic $\mathrm{Cr}$ coating [15].

\begin{tabular}{|c|c|c|c|c|c|c|}
\hline \multirow{2}{*}{ Flow speed m/s } & \multicolumn{6}{|c|}{ Distance from tube end, mm } \\
\cline { 2 - 7 } & 0 & 100 & 200 & 300 & 400 & 495 \\
\hline 0 & 25 & 25 & 18 & 22.2 & 30.3 & 6 \\
\hline 1.2 & 24.5 & 25 & 30.5 & 28.5 & 35.5 & 11.8 \\
\hline 1.6 & 26.3 & 33.3 & 35 & 36.4 & 36 & 10.8 \\
\hline 2.0 & 26.4 & 29.1 & 30.3 & 35 & 44.3 & 14 \\
\hline
\end{tabular}

[10] as a substitute for conventional nanocrystal line chromium coatings. This article aims to present possible solutions to refund $\mathrm{Cr}$-electroplated coating and assess the effectiveness of alternative compensation. The literature has already mentioned disclosed methods, especially:

a) Replacing $\mathrm{Cr}$ with another element with preservation of the original technology.

b) Thermal spraying.

c) Coating through explosion.

d) Vacuum physical and chemical methods (PVD, CVD) or their combination by ion implantation.

Alternative methods of replacement of $\mathrm{Cr}$ galvanic coatings:

a) Electrolytic coating of other elements: hexavalent chromium can be replaced by cobalt [11] and chemical reaction as shown in Fig. 2a). In galvanic coating the coat is generated by electrochemical reaction using electricity on the inner surface of the head cannon. The process takes place in a special bath (the electrolyte) captured by a direct fluxion. A coated tube is connected to the negative terminal. The anode is made up of metal, which excludes the object metal coating and is connected to the positive pole of the source. Plating parameters (current density, voltage, current) are the subject of know-how technology of the Rowan Company [12], which deals with creating that type of coat.

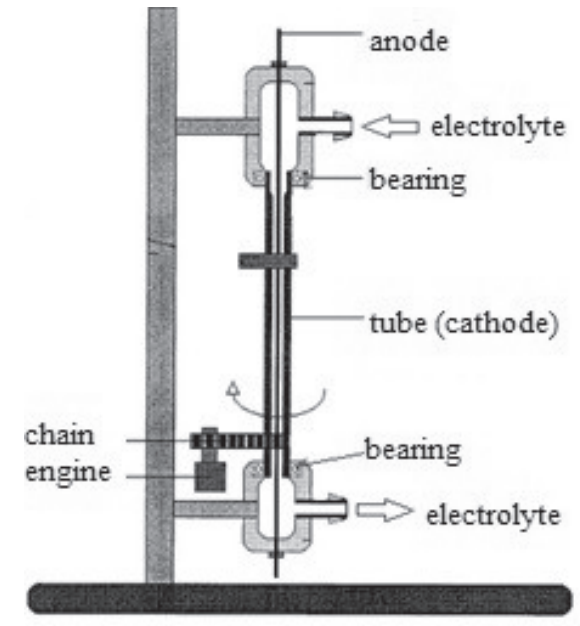

Fig. 1. Electrolytic formation of $\mathrm{Cr}$ coating on the inner surface of the roller [15]. b) Thermal spraying: Fig. $2 b$ describes thermal spraying technology - high-speed thermal spraying and spraying high-velocity oxygen fuel (HVOF) - for coating the inner surface of a tube [13]. The limiting factor is the minimal diameter. By contrast to other technologies of coating, dip injection is not based on the overlap of atoms, but hole melted (or partially fused) particles of the coating material strike upon the surface. Particles of the coating material adhere only to the surface of bodies lying in the path of flying fused particles. The technology of thermal spraying (Fig. 2b) allows for creating a coating of ceramics, metals, and their alloys, in which there is no disintegration of the melting point, almost on all types of substrate materials. This is made by mechanical anchoring of the coating to the roughened surface of the substrate.

Technological process assures the temperature of coated parts below the temperature of the structural phase-transformation (about $80-120^{\circ} \mathrm{C}$ ). It also prevents unwanted distortion of components. The type of used energy can be divided into methods of thermal spraying as shown in Fig. 4. For each type of energy, it is possible to distinguish certain characteristic values and features which these types of energy significantly differ. These are mainly the following parameters:

- Achieved maximum energy density per unit area.

- Maximum temperature values obtained with various energy sources.

Thermal spraying methods are divided into two groups:

- Methods using the heat energy of burning a mixture of fuel and oxygen:

- Thermal spraying flame.

- Detonation spraying (D-gun).

- High-speed spraying (HVOF).

- Methods using thermal energy of power source:

- Plasma spraying (plasma spraying in air, vacuum plasma spraying, radiofrequency plasma spraying).

- Electric arc spraying.

The analysis of various methods of thermal spraying and physical parameters show the differences, advantages, and disadvantages of each technology of thermal spraying. Knowledge of these issues can compare these technologies (Fig. 4, Table 2) and select the appropriate method of thermal spraying as replacement galvanic chrome. An overview of parameters of individual methods of thermal spraying, some properties of the coating produced by these methods, and their most common use are shown in Table 2. Hard chrome plating is used for a very wide range of applications, from which results too many choices replace hard chrome plating. This includes plating with alternative alloys, for example CVD and PVD (sputtering, vapour plating, ion nitriding). The greatest potential compensation for hard chrome plating, however, is found in thermal sprayed coatings. Thermal spraying technologies are based on the principle where the material is applied as a powder (or wire) supplied to the heat source (plasma, flame, el. arc) where the particles are melted down and accelerated toward the coating part. 

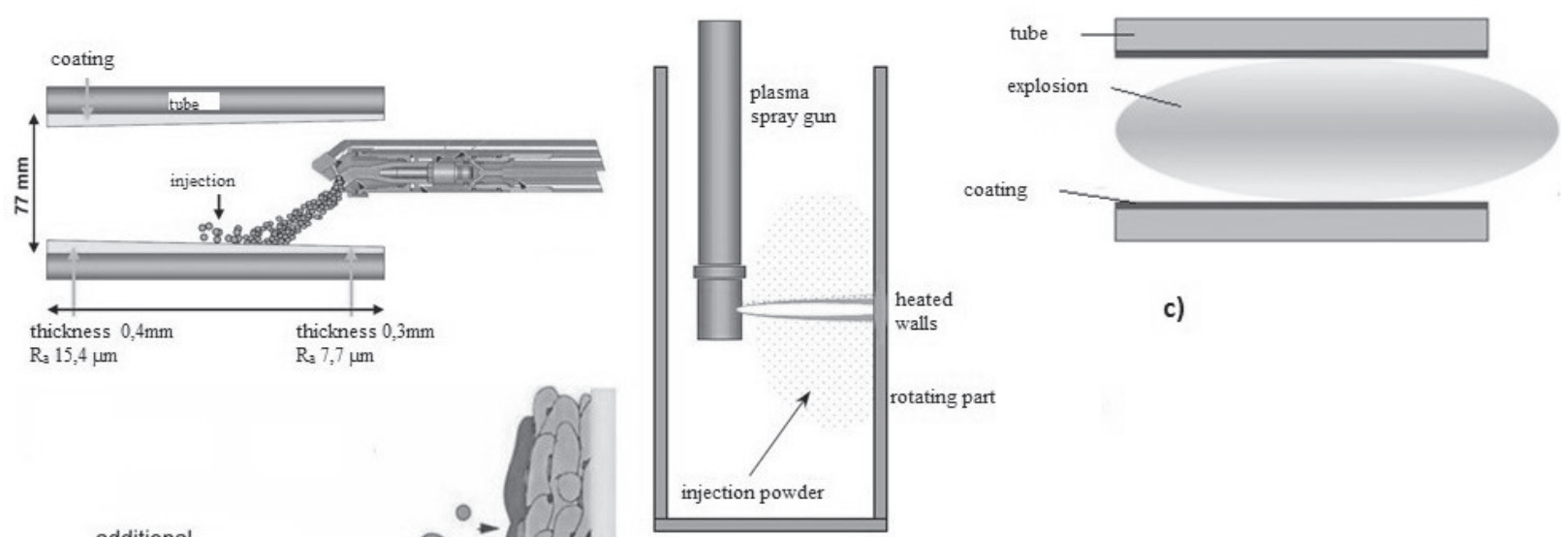

c)

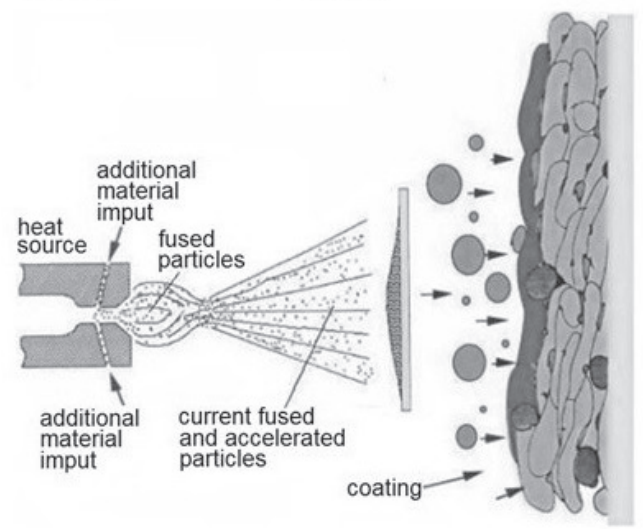

b)

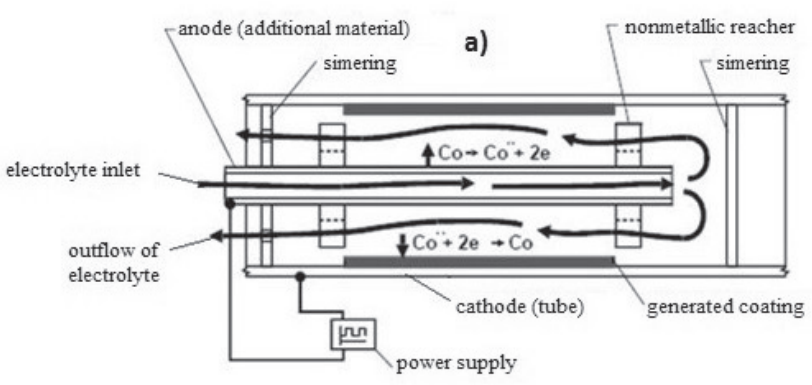

Fig. 2. a) Galvanic coating of hollow part [11], b) Galvanic coating of tube [13] with diagram of creation process of thermal spraying, and c) Technology of coating by explosion [11].

Excessive particle dissipation, anchoring, and accelerated curing occur in the event of an impact. This creates a coating with a characteristic lamella structure.

c) Coating by explosion: another technology of coating the internal surface is coating by explosion (Fig. 2c), which is investigated as an alternative to galvanic chrome plating and thus hexavalent chromium [11].
Kinetic energy of the explosive blast is used to move coating material to the functional surface, which also ensures satisfactory adhesion of the deposited coating.

d) Vacuum methods: literature [14] assessed anisotropy CrN coatings by magnetic sputtering, which is also known as cylindrical magnetron sputtering (Fig. 3a),
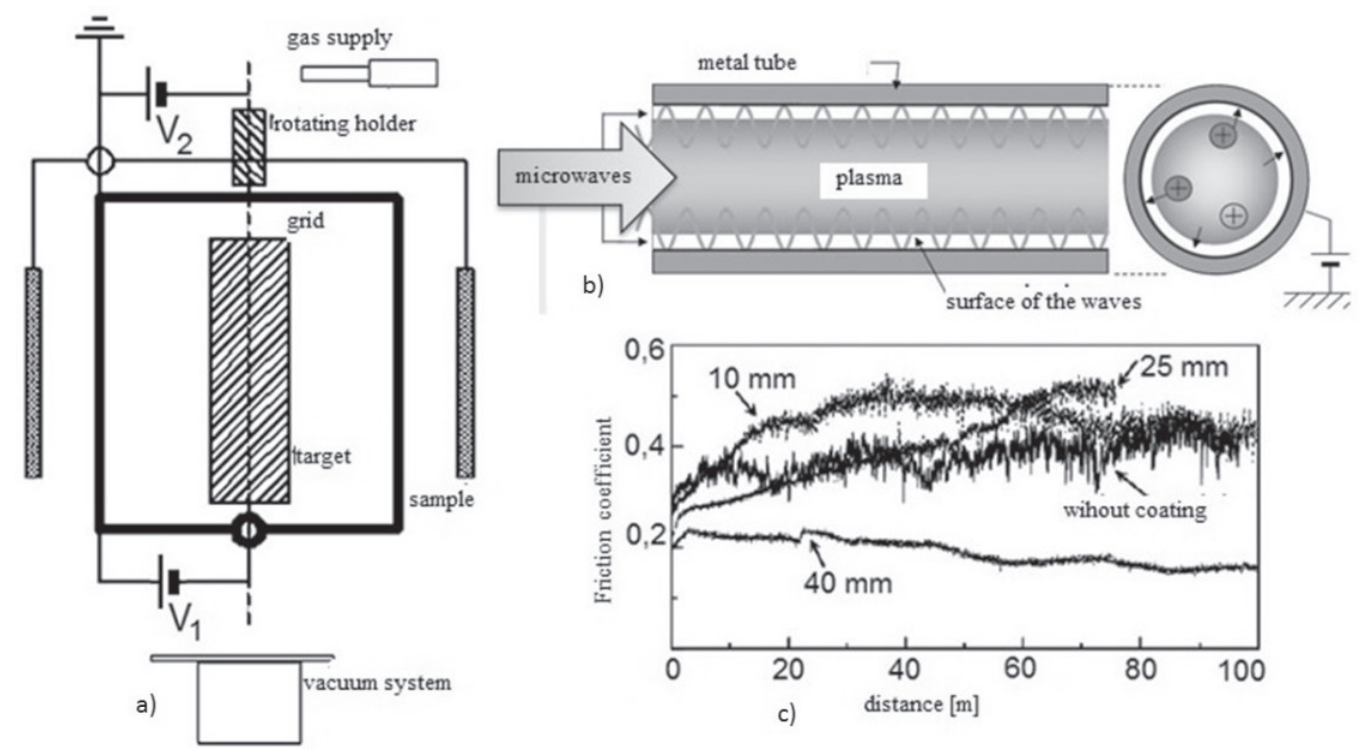

Fig. 3. a) Galvanic coating of hollow part [14], b) PECVD method, plasma-directed by microwaves [14], and c) Friction coefficient according to distance [14]. 


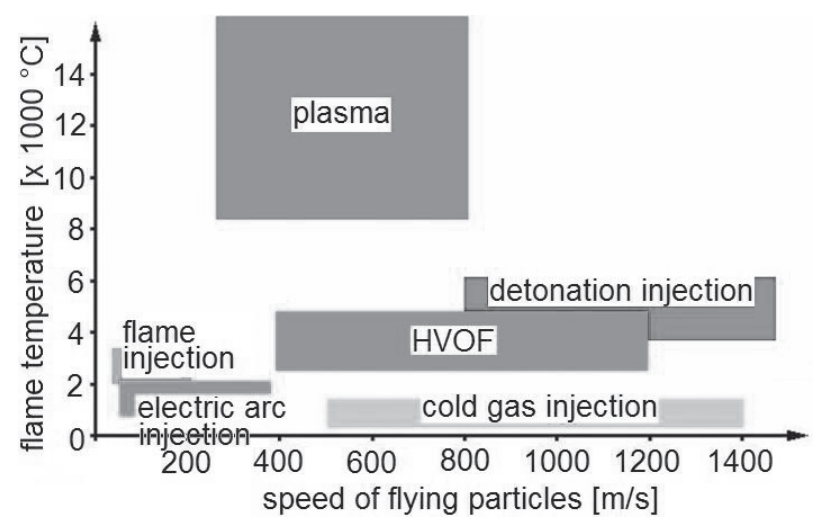

Fig. 4. Comparison of thermal spraying processes in terms of temperature and speed of the impacting particles [24].

described by $\mathrm{K}$. Legg in his work about replacing a hard $\mathrm{Cr}$ and $\mathrm{Cd}$ and choosing the best options [12]. Sputtering technological parameters were: current of $0.8 \mathrm{~A}$, voltage $350 \mathrm{~V}$, bias $1100 \mathrm{~V}$, pressure in the vacuum chamber of $0.3 \mathrm{~Pa}$, working gas was pure Ar, and the reaction gas was $\mathrm{N}_{2}$. As a target we used clean Cr. Kousaka H. et al. [12] used for deposition of the diamond like carbon (DLC) coating method plasma enhanced chemical vapour deposition (PECVD), and for directing plasma used we microwaves (Fig. 3b). A steel tube had a diameter of $4.4 \mathrm{~mm}$ and a length of $200 \mathrm{~mm}$. The friction coefficient was evaluated by pin-on-disk test according to the distance from the entrance to the tube (Fig. 3c). Test parameters were: loading forces of $19.6 \mathrm{~N}$, the speed of the counterpart cast-iron balls $26.4 \mathrm{~mm} / \mathrm{s}, 4.2 \mathrm{~mm}$ diameter beads, and Hertz contact pressure of $22 \mathrm{MPa}$. The hardness of the coating was evaluated at intervals of $5 \mathrm{GPa}$ to $12 \mathrm{GPa}$.

\section{Materials and Methods}

Methods used to replace the production of coatings and their materials were selected according to the properties of produced coatings (hardness, adhesion, wear resistance, friction coefficient). Listed coatings are always used in connection with temperature, operating pressure, load force, lubricant use, and others.

These spare technologies include: thermal spraying, PVD and CVD technologies, and ion implantation. Using these technologies, the thickness of the layers may range from several nanometers to $1-5 \mathrm{~mm}$. The choice of technology and layer thickness is influenced by the aforementioned operating parameters. For example, the telescopic parts of aircraft landing gear are degraded differently in the case of aircraft operating at sea (aggressively corrosive environment, the presence of salt in the air), if the aircraft is in a desert region (degrading mechanism abrasive and erosive due to the presence of small silica particles in the air, also a high temperature range of $\left.0-60^{\circ} \mathrm{C}\right)$. In the case of flights in Central Europe, temperatures and airborne particles are acceptable, but polar circle flying at low temperatures $\left(-70-0^{\circ} \mathrm{C}\right)$ also includes the presence of salt.

The elimination of chromium from an electrolyte consisting of chromic acid and the companion catalysing acid (sulfuric, hydrofluoric, fluorosilicic) extends through gradual reduction of chromium $\mathrm{CrO}_{3}$ through substances of chromium with lower valences to metallic chromium, and eventually chromium is eliminated from the chromic

Table 2. Results of comparison of methods of thermal spraying [2-5, 24-26].

\begin{tabular}{|c|c|c|c|c|c|c|c|}
\hline $\begin{array}{l}\text { Injection } \\
\text { technology }\end{array}$ & $\begin{array}{l}\text { Form of } \\
\text { additive } \\
\text { material }\end{array}$ & $\begin{array}{c}\text { Source } \\
\text { temperature } \\
(\%)\end{array}$ & $\begin{array}{l}\text { Speed of } \\
\text { particles } \\
(\mathrm{m} / \mathrm{s})\end{array}$ & $\begin{array}{c}\text { Adhesion } \\
\text { (adhesion) } \\
(\mathrm{MPa})\end{array}$ & $\begin{array}{l}\text { Typical } \\
\text { sprayed } \\
\text { materials }\end{array}$ & $\begin{array}{l}\text { Properties of the } \\
\text { coating }\end{array}$ & $\begin{array}{c}\text { Suitable } \\
\text { applications }\end{array}$ \\
\hline $\begin{array}{l}\text { Flame } \\
\text { injection }\end{array}$ & Powder/wire & $2,700-3200$ & $50-100$ & $7-18$ & $\begin{array}{c}\text { metals, alloys, } \\
\text { plastic }\end{array}$ & $\begin{array}{l}\text { higher porosity and } \\
\text { oxide content }\end{array}$ & $\begin{array}{c}\text { classical } \\
\text { metallization, } \\
\text { less demanding } \\
\text { applications }\end{array}$ \\
\hline $\begin{array}{l}\text { Detonation } \\
\text { injection }\end{array}$ & Powder & $4,000-6,000$ & $\begin{array}{l}1,000 \text { and } \\
\text { more }\end{array}$ & 82 & $\begin{array}{c}\text { metals, alloys, } \\
\text { cermet }\end{array}$ & $\begin{array}{l}\text { high hardness, low } \\
\text { porosity and oxide } \\
\text { content }\end{array}$ & wear protection \\
\hline Hvof & Powder & $2,800-5,200$ & $200-1,200$ & $60-90$ & $\begin{array}{c}\text { metals, alloys, } \\
\text { cermet }\end{array}$ & $\begin{array}{c}\text { high density, } \\
\text { excellent adhesion, } \\
\text { compressive stress }\end{array}$ & $\begin{array}{l}\text { protection against } \\
\text { wear, corrosion }\end{array}$ \\
\hline $\begin{array}{l}\text { Plasma } \\
\text { injection }\end{array}$ & Powder & $\begin{array}{l}12,000- \\
20,000\end{array}$ & $100-800$ & $+/-68$ & ceramics & $\begin{array}{c}\text { porous in the case } \\
\text { of ceramics }\end{array}$ & $\begin{array}{l}\text { Thermal barrier, } \\
\text { isolators }\end{array}$ \\
\hline $\begin{array}{l}\text { Electric arc } \\
\text { injection }\end{array}$ & Wire & $4,000-8,000$ & $50-300$ & $10-40$ & $\begin{array}{c}\text { metals, alloys, } \\
\text { cermet }\end{array}$ & $\begin{array}{l}\text { greater thickness, } \\
\text { high density }\end{array}$ & $\begin{array}{l}\text { wear resistant } \\
\text { coatings, } \\
\text { renovations }\end{array}$ \\
\hline $\begin{array}{l}\text { Cold gas } \\
\text { injection }\end{array}$ & Powder & less than 900 & $500-1,500$ & - & $\begin{array}{l}\text { soft metals } \\
\text { and their } \\
\text { alloys }\end{array}$ & $\begin{array}{l}\text { greater thickness, } \\
\text { low oxide content }\end{array}$ & $\begin{array}{l}\text { corrosion protection, } \\
\text { conductive coatings }\end{array}$ \\
\hline
\end{tabular}


acid directly, without intermediate reduction stages. The authors have dealt with research of $\mathrm{Cr}$ electroplating coating for several decades [2-5].

Several studies in literature [15] deal with properties of $\mathrm{Cr}$ coatings deposited electrolytically. They have coated the internal surface of a diameter of $7.62 \mathrm{~mm}$ (copper) and $5.56 \mathrm{~mm}$ (steel) and a length of $150 \mathrm{~mm}$ (copper) and $495 \mathrm{~mm}$ (steel) (Fig. 1). Coating processes used anode, which passed the axis of the tube. Technological parameter depositions of $\mathrm{Cr}$ coating are: current density $26 \mathrm{~A} / \mathrm{dm}^{2}$, temperature of the electrolyte was $50^{\circ} \mathrm{C}$, and flow rates of the electrolyte were $1.2 \mathrm{l} / \mathrm{min} ., 1.6 \mathrm{l} / \mathrm{min}$., and $2.0 \mathrm{l} / \mathrm{min}$. The main ingredients of the electrolyte are: phosphoric acid (48 wt \%), sulfuric acid (48 wt \%), and $\mathrm{H}_{2} \mathrm{O}(2 \mathrm{wt} \%)$. The thickness of $\mathrm{Cr}$ coating was in the range 6-44.3 microns, with a value decreasing according to the flow rate of electrolytes, and the distance of the inlet to the tube. The hardness of the coating was $840 \mathrm{HV}$ to $920 \mathrm{HV}$ depending on electrolyte flow rate and the speed of rotation of the coated tube (Fig. 2c). In evaluating the thickness, current density and diameter of the anode were constant, changing the flow of the electrolyte. It is possible to obtain high hardness, coefficient of friction (COF), and acceptable corrosion resistance at an elevated temperature $[11,15]$.

\section{Results and Discussion}

For selection of a suitable coating material and method of its deposition in order to replace Cr-galvanized coating, it is necessary to compare selected properties of $\mathrm{Cr}$ coating and alternative coatings. First of all, it is necessary to compare the features of $\mathrm{Cr}$ coatings deposited galvanically and then the same characteristics of the proposed compensation. The most important properties of coating include: hardness, thickness, coefficient of friction, and abrasion. Table 3 summarizes selected features and values of Cr-galvanized coating. Table 3 shows that the highest hardness was obtained by Martinkovič et al. [16], where hardness reached the value of $11.4 \mathrm{GPa}$. This value is up to $40 \%$ higher. The value of COF $=0.13$ of these authors is markedly lower than Martinkovič et al. [16]. The value is $\mathrm{COF}=0.71$. On the other hand, $\mathrm{COF}$ takes the values of 0.70 . The thickness of coating was $90 \mu \mathrm{m}$. Presented values of measured properties have been achieved

Table 3. Published values of selected properties of $\mathrm{Cr}$ galvanized coating.

\begin{tabular}{|c|c|c|c|c|c|c|c|}
\hline Reference & 1 & 2 & 3 & 4 & 23 & 24 & $8^{*}$ \\
\hline Thickness $[\mu \mathrm{m}]$ & 50 & 50 & - & 40 & 80 & 15 & 5 \\
\hline Hardness $[\mathrm{GPa}]$ & 9.2 & 8.4 & 8.8 & 10.3 & 8.9 & 9.0 & 8.4 \\
\hline FC & - & - & - & 0.58 & 0.2 & 0.8 & - \\
\hline
\end{tabular}

Values of hardness at RT showed in literature; *trivalent electroplated $\mathrm{Cr}$ coating
Table 4. Selected deposition parameters of $\mathrm{Cr}$ coatings in selected literature.

\begin{tabular}{|c|c|c|c|c|}
\hline Reference & 1 & $2-4$ & 23 & 8 \\
\hline $\mathrm{CrO}_{3}(\mathrm{~g} / \mathrm{l})$ & 250 & 250 & 250 & 50 \\
\hline $\mathrm{H}_{2} \mathrm{SO}_{4}(\mathrm{~g} / \mathrm{l})$ & 2.5 & 2.5 & 2.5 & 2.0 \\
\hline Current density $\left(\mathrm{A} / \mathrm{dm}^{2}\right)$ & 40 & 60 & 85 & 135 \\
\hline Deposition temperature $\left({ }^{\circ} \mathrm{C}\right)$ & 55 & 55 & 85 & 60 \\
\hline
\end{tabular}

in altered amounts of individual components of the electrolyte. Other mentioned authors especially evaluated hardness, whose measured value was in the range of 8.4 $\mathrm{GPa}$ to $10.3 \mathrm{GPa}$. An overview of the most important parameters of deposition electrolyte $\mathrm{Cr}$ coating is shown in Table 4, which shows that the high value of hardness was measured on Cr coating, which has been deposited with significantly altered technological parameters. Especially the amount of electrolyte components as $\mathrm{CrO}_{3}$ and $\mathrm{H}_{2} \mathrm{SO}_{4}$ were significantly lower versus the compared authors. On the other hand, the thicknesses of the thermal spraying and HVOF WC-Co coatings are in the range $0.5-350 \mu \mathrm{m}$ and $\mathrm{COF}$ was in the range 0.24 0.31 . There are also successfully used layers of $\mathrm{CrC}$ and NiCo $[1,3]$, then layers of WC-Co-Cr deposited by the $\mathrm{HVOF}$ method. Its hardness is 24.5 GPa [7]. Hardness of the WC-Co layer is approximately $\mathrm{GPa}$, and $\mathrm{COF}$ from 0.5 to 0.8 . The hardness of $\mathrm{Cr}_{2} \mathrm{O}_{3}$ coatings is about 12.5 $\mathrm{GPa}$ [7]. This is the reason for usage of abovementioned materials and technologies for replacement of electro-deposited Cr coatings.

Another method is PECVD technology, which can be on deposit as a spare coat as CrSiCN, DLC coating, and others. Deposited thickness ranges 1.0-5.0 $\mu \mathrm{m}$ as a monolayer up to $30 \mu \mathrm{m}$ as a multilayer. In the case of multilayer, the intermediate layers are arranged to ensure good adhesion (to steel substrate, Al alloy substrate, Ti intermediate layer). In successive steps, further intermediate layers are structured so that the hardness increases to a maximum value of the top layer, which ensures good wear resistance. The hardness of the top coat ranges 20.0-35.0 GPa. An overview of measured hardness, thickness, $\mathrm{COF}$, and material of evaluated coatings and methods of deposition are shown

Table 5. Rated HVOF properties and electrolytically deposited coatings as a replacement for $\mathrm{Cr}$ electrodeposition coating.

\begin{tabular}{|c|c|c|c|c|c|}
\hline Reference & 1 & 3 & 4 & 9 & 15 \\
\hline Coating & $\mathrm{CrC}$ & $\mathrm{CrC}$ & $\mathrm{NiP}$ & Ni-Co & Ni-Mo-Co \\
\hline $\begin{array}{c}\text { Thickness } \\
{[\mu \mathrm{m}]}\end{array}$ & 50 & $40-50$ & 33 & 45 & 20 \\
\hline $\begin{array}{c}\text { Hardness } \\
{[\mathrm{GPa}]}\end{array}$ & 8.5 & 8.0 & 5.6 & 5.0 & 7.3 \\
\hline FC & - & - & 0.45 & - & 0.5 \\
\hline
\end{tabular}


in Table 5. In $[1,3,4,9,15]$ films were electrochemically deposited from the electrolyte. The research is realised from materials other than $\mathrm{Cr}$. Rated properties such as hardness and COF are comparable with the results of coatings deposited by the HVOF method. In spite of this, HVOF coatings do not have such an adverse effect on the environment because they do not leave electrolytes that must be ecologically spread.

\section{Selecting a Method for Replacing Galvanic Coatings}

Toxicity of chemicals may strongly depend on the form in which they exist in the environment. The adverse effects when disposing of output after applying plating technology with hexavalent chromium $\mathrm{Cr}^{6+}$ should be noted, and in this regard the possibility of compensation. Hexavalent chromium $\mathrm{Cr}^{6+}$ pollutes soil, water, and air, making it dangerous for all living organisms. The main component of chromium bath is chromium trioxide. During the process of chroming, its concentration is in the range 200-300 g/l. The optimal concentration is $250 \mathrm{~g} / \mathrm{l}$ when the cathodic current yield is the highest. The effort to reduce the yield of hexavalent chromium (hexavalent chromium $\mathrm{Cr}^{6+}$ ) in wastewater can be found at a concentration of chromium oxide in the range of 150-200 g/l, calling for new types of catalysts. This is the right choice and then their concentration significantly affects the operation and economy of chromium bath. Primary catalysts are sulfate in the form of $\mathrm{H}_{2} \mathrm{SO}_{4}$. Simple fluoride and complex salts containing fluoroborate anion have a catalytic effect. The presence of these substances in the bath increase cathodic current yield, but also significantly increase the aggressiveness of electrolyte against the base material.

There is an increased dissolution of iron in the chromate bath that subsequently leads to depreciation [17]. The chrome plating process involves the production of hydrogen, which escapes from the bath into the atmosphere. Contemporaneously, it brings out a considerable amount of chromium bath in the form of acidic and very aggressive aerosols. To reduce the amount of aerosols, special surfactants are added to the bath [18]. They form a low foam bath on the surface, and a substantial portion of aerosol is captured. The addition of surfactant significantly reduces the requirements for quantity of exhausted air above the bath [6, 19-20]. Unwanted components of chromium bath are metal ballasts. They get into the bath by dissolving the base material of chrome parts. These represent mainly iron, trivalent chromium, and some heavy metals. If the process of roughening is performed before chrome plating, the amount of dissolved iron ballast increases. The chromium ions are parts of chromium electrolytes. In the process of chromium hexavalent chromium $\mathrm{Cr}^{6+}$ is reduced to metal. This is a cathodic current yield, which compared to other plating baths is very low. Another
$30 \%$ of flux is consumed for the reduction of hexavalent chromium to trivalent, which remains being dissolved in the electrolyte. The rest of the supplied flux is consumed for generating hydrogen. Even more important, trivalent chromium in solution is recovered at the anodes, and about $30 \%$ is oxidized back to hexavalent chromium $\mathrm{Cr}^{6+}$.

There is a balance between reduction and oxidation at a concentration of about $5 \mathrm{~g} / \mathrm{l}$ of $\mathrm{Cr}$ on the electrolyte. This amount is considered as optimal for chrome plating. The growth of such impurities causes a reduction in the current yield, reducing the conductivity of the bath, and increasing the terminal voltage and power consumption. Most critical is concentration of ballast between 17-20 $\mathrm{g} / \mathrm{l}$. At this concentration, the bath practically ceases to chrome [17, 20]. Application of this technology requires a focus on ecologization of outputs from this process. Technological possibilities for the renewal of valuable chemicals from wastewater and gases and assessing the impact of modernization on water quality is covered in detail in literature [21]. Utilizing Ni as part of the abovementioned combination can also be considered a health risk [4, 21,27]. Although the majority of nickel gets in the human body from drinking water and food, a greater negative impact on health is inhalation (such as during application coatings), which is highly toxic and comes with carcinogenic effects.

The most appropriate technology for replacing hard chrome plating is a technology called high velocity oxygen fuel (HVOF). This method is used to coat the base metal alloys, super alloys, cermet, ceramics, and polymers, and substantially all of the common types of base materials. The main advantage of the HVOF sprayed coatings is low porosity (less than 1\%), high adhesion (exceeding $80 \mathrm{MPa}$ ), and low oxide content (less than $1 \%$ ) for the feed of reactive metals. The latest burners for HVOF spray are the so-called third-generation burner (JP, e.g., TAFA 5000, DJ 2600, DJ 2700, JetKote II) which allow for the creation of compressive stress in the coating, which is very favourable for fatigue properties of coated elements. It is also possible to apply a coating with a thickness of several millimetres. The advantage of HVOF coatings compared to hard chrome plating is the possibility of material choice and thus the accomplishment of exact requirements of a given application. This is a variety of materials suitable as a replacement for hard chrome plating, but the most appropriate is coating WC$\mathrm{Co}$, which covers the widest range of applications of hard chrome plating [8]. The advantages of HVOF sprayed coatings compared with hard chrome plating materials are:

- The possibility of material choice.

- Better wear resistance, corrosion, and fatigue properties.

- Thicker coatings without surface network cracks.

- Deposition rates.

- Independence on the base material due to mechanical anchoring sprayed coatings.

- Infrequent renovation of parts due to their longer life. 
- Heat treatment of hydrogen embrittlement is not required, which is particularly important for large parts.

- Unlimited size of components.

- Uniform thickness of coating.

- Environmentally preferable.

- Cleaner and safer operation, eliminates the problem of cleaning bath and rinse water.

- It is not needed to store toxic substances.

- Waste in the form of overspray can be recycled or used in another way.

The issue of compensating the hard chrome plating has been intensively studied around the world in recent years. The evidence is a number of publications and ongoing projects dealing with these issues, but on the other hand - thanks to a competitive environment - it is almost impossible to obtain detailed information. The biggest effort is seen primarily in the aerospace industry, where companies such as Boeing, Rolls Royce, Lufthansa, and Delta Airlines are concerned with replacement of hard chrome plating [6,22]. Currently Lufthansa has conducted flight tests with the aircraft that contain thermally sprayed parts that were first hard-chrome plated. The company considers complete replacement of hard chrome plating for repairs of all aircraft.

\section{Economic Evaluation of Alternate Methods of Coating}

This economic evaluation is a comparison of costs used in the process of thermally sprayed coatings using the HVOF method, and the technology of hard chrome plating of hydraulic elements. Specifically, we take into account the cluster coating of filler material Fe $17 \%$. The company TePU, Ltd. has experience with this element and uses it for these applications. We not only considered hydraulic components, but the overall cost associated with production, operation, maintenance, and the need for replacing worn components.

Prices are only informative because they may change due to various factors. The price of hard chrome is published online. Information about the cost for providing a coating of filler material $\mathrm{Fe} 17 \% \mathrm{Cr}$ was provided by TePU. The price of hard chrome at a thickness of $0.1 \mathrm{~mm}$ and a simple cylindrical form of a part is $0.2-0.6 € / \mathrm{cm}^{2}$. The price of the coating of a thickness $0.2-0.3 \mathrm{~mm}$ is 0.2-0.6€/ $\mathrm{cm}^{2}$. The price of dip spraying (HVOF) is therefore at least three times more expensive, but with 3-5 times greater guarantee of durability. This fact favours the technology of thermal spraying. The coating formed by hot spraying has a significantly lower consumption of sealant - 2-3 times lower than in the case of hard chrome plating. This is important only in cases where equipment with hydraulic components is used in continuous operation, where each service downtime decreases productivity.

In the process of hard chrome surface treatment, the plated part must be without any defects on the surface (although there can be some defects in the form of micro cracks). These micro cracks may cause an undercutting of coating, its breach, deterioration, or even stop hydraulic elements altogether. This increases the cost of production and in the case of bad pre-treatment it reduces the service life of hydraulic components with hard chrome.

Another aspect that increases costs in the process of hard chrome plating is costs connected to the degradation of hexavalent chromium. So-called hexavalent chromium is very aggressive in the environment, therefore it is necessary to neutralize the electrolyte by degrading the element. Finally, the HVOF method compared to hard chrome plating is more advantageous in terms of quality and also cheaper in terms of durability - despite the higher initial cost.

\section{Conclusions}

The significant desired properties of $\mathrm{Cr}$ coating technology are hardness, coefficient of friction, and wear and corrosion resistance. The features can be influenced by process parameters: current density and temperature of the electrolyte. Moreover, the composition of electrolyte material is very important. It often consists of sulfuric acid, phosphoric $\mathrm{CrO}_{3}$, or other important additives. Furthermore, also percentage composition of components of the electrolyte is very important. Based on the discussions it can be concluded that the substitution of $\mathrm{Cr}$ coatings deposited electrolytically is not easy. One of the reasons is its outstanding features, especially hardness and abrasion resistance. Most of these characteristics meet coatings based on WC-Co deposited by the HVOF method. Through research of coatings is deposited electrolytically, it can be stated that HVOF coatings do not have such adverse effects on the environment, because they do not leave electrolytes that must be organically decomposed. Selection of deposition parameters is currently under investigation.

As mentioned in our economic evaluation, surface modification by method of thermal spraying significantly prolongs the life cycle surface modification of machine parts. It has a benign influence on economic and environmental aspect. In the case of hydraulic systems, coatings formed by cluster coating technology have a better tightness, and the possibility of leaking the hydraulic fluid into the environment decreases. There is also the possibility of renovation of machine parts by the thermal spraying method, which has to be decommissioned. It also allows for better use of natural resources, which is very important in the long term. It would be also appropriate to focus on the resistance of plaque against erosion, resistance of coating against corrosion, friction coefficient, and percentage of porosity, hardness, and homogeneity of the coating. 


\section{Acknowledgements}

This article was created by implementing grant project VEGA 1/0708/16: Development of new research methods for simulation, assessment, evaluation, and quantification of advanced methods of production and grants; and VEGA 1/0432/17: Research of nanocomposite hard coatings to improve the functional properties of engineering parts.

\section{References}

1. ZENG Z., ZHANG J. Anti-wear properties of $\mathrm{Cr}-\mathrm{C}$ and $\mathrm{Ni}-\mathrm{Co}$ alloy coatings as substitutes for conventional nanocrystalline $\mathrm{Cr}$ coatings, Journal of Physics D: Applied Physics 41, 2008.

2. ZENG Z., WANG L., CHEN L., ZHANG J. The correlation between the hardness and tribological behaviour of electroplated chromium coatings sliding against ceramic and steel counterparts, Surface and Coatings Technology 201 (17-18), 2006.

3. ZENG Z., WANG L., LIANG A., ZHANG J. Tribological and electrochemical behavior of thick $\mathrm{Cr}-\mathrm{C}$ alloy coatings electrodeposited in trivalent chromium bath as an alternative to conventional $\mathrm{Cr}$ coatings, Electrochimica Acta 52, 2006.

4. WANG L., GAO Y., XUE Q., LIU H., XU T.A. novel electrodeposited $\mathrm{Ni}-\mathrm{P}$ gradient deposit for replacement of conventional hard chromium, Surface and Coatings Technology 200, 2006.

5. HUANG C.A., LIN W., LIAO M.J. The electrochemical behaviour of the bright chromium deposits plated with direct- and pulse-current in $1 \mathrm{M} \mathrm{H}_{2} \mathrm{SO}_{4}$, Corrosion Science 48, 2006.

6. SANIUK S., SANIUK A. Rapid prototyping of constraintbased production flows in outsourcing. Advanced Materials Research. 44-46 (1), 355, 2008.

7. BREZINOVÁ J., VIŇÁŠ J., GUZANOVÁ A. Hodnotenie kvality keramických povlakov $\mathrm{V}$ podmienkach tribologického a cyklického tepelného zat’aženia, Chemical letters - Chemické listy, 105 (16), 574, 2011.

8. SRIVASTAVA M., EZHIL SELVI V., WILLIAM GRIPS V.K., RAJAM K.S. Corrosion resistance and microstructure of electrodeposited nickel-cobalt alloy coatings, Surface Coatings and Technology 201 (3051-3060), 2006.

9. SRIVASTAVA M., ANANDAN C., WILLIAM GRIPS V.K. Ni-Mo-Co ternary alloy as a replacement for hard chrome, Applied Surface Science 285 (Part B), 167, 2013.

10. PRIOTEASA P., ANICAI L., VISAN T. Synthesis and corrosion characterization of electrodeposited $\mathrm{Ni}-\mathrm{Mo}$ alloys obtained from aqueous solutions, U.P.B. Scientific Bulletin, Series B: Chemistry and Materials Science 72, 11, 2010.

11. LEGG K. Replacing hard $\mathrm{Cr}$ and $\mathrm{Cd}$ - choosing the best options, [online] [cit. 19-02-2007]: www.rowantechnology. com, 2007.

12. KOUSAKA H., MORI K., UMEHARA N., TAMURA N., SHINDO T. Internal DLC coating of narrow metal tubes using high-density near plasma sustained by microwaves propagating along plasma-sheath interfaces, Surface and Coating Technology 229, 65, 2013.
13. LEGG K., SARTWELL B. Plasma spray of internal diameters, SERDP Project 1151, [online], [cit-11-03-2009]: http:/www.rowantechnology.com/Documents/Plasma\%20 Spray/NDCEE\%20Cr\%20Cd\%20Ni\%20SERDP\%20ID. pdf, 2009.

14. ZENG F., LIANG R., LI X.W., WEN S.P., GAO Y., GU Y.L., PAN F. Surface anisotropy of $\mathrm{Cr}_{\mathrm{x}} \mathrm{N}_{1-\mathrm{x}}$ films prepared on an inner wall by magnetic sputtering, Applied Surface Science 253, 7563, 2007.

15. YIN K.M., WANG C.M. A study on the deposit uniformity of hard chromium plating on the interior of small-diameter tubes, Surface and Coating Technology 114, 213, 1999.

16. MARTINKOVIČ M., KOTTFER D., FERDINANDY M., MAŇKOVÁ I. The characterization of electroplated $\mathrm{Cr}$ coating, Mater. Sci. Technol. (internet magazine), 2, 31, 2011.

17. SØR-TRØNDELAG. University College, Faculty of Technology [cit-21-03-2017]: <http://histproject.no/sites/ histproject.no/files/2_18_Ochranné_vrstvy.pdf $>$.

18. DANILOV F.I., PROTSENKO V.S., GORDIIENKO V.O., KWON S.C., LEE J.Y., M. KIM M. Nanocrystalline hard chromium electrodeposition from trivalent chromium bath containing carbamide and formic acid: Structure, composition, electrochemical corrosion behavior, hardness and wear characteristics of deposits, Appl. Surf. Sci., 257, 8048, 2011.

19. MALINDZAKOVA M., STRĄKA M., ROSOVA A., KANUCHOVA M., TREBUNA P. Modeling the process for incineration of municipal waste, Przemysl Chemiczny, 94 (8), 2015.

20. KRAUS V. Povrchy a jejich úpravy [cit-21-03-2017]: <http:// tzs.kmm.zcu.cz/POUcelk.pdf $>$.

21. DĄBROWSKA J., BAWIEC A., PAWĘSKA K., KAMIŃSKA J., STODOLAK J. Assessing the Impact of Wastewater Effluent Diversion on Water Quality, 1-12 [cit20-03-2017]: http://www.pjoes.com/pdf/9.1/45-56.pdf, 26 (1), 2017.

22. KŁOS S., PATALAS-MALISZEWSKA J. Throughput analysis of automatic production lines based on simulation methods, 93-75, 2015.

23. BELTOWSKA-LEHMAN E., INDYKA P. Kinetics of $\mathrm{Ni}-\mathrm{Mo}$ electrodeposition from Ni rich citrate baths, Thin Solid Films 520, 2046, 2012.

24. AABOUBI O. Hydrogen evolution activity of $\mathrm{Ni}-\mathrm{Mo}$ coating electrodeposited under magnetic field control, International Journal of Hydrogen Energy 36, 4702, 2011.

25. WESTON D.P., SHIPWAY P.H., HARRIS S.J., CHENG M.K. Friction and sliding wear behaviour of electrodeposited cobalt and cobalt-tungsten alloy coatings for replacement of electrodeposited chromium, Wear, 267, 934, 2009.

26. DE LIMA-NETO P., CORREIA A.N., VAZ G.L., CASCIANO P.N.S. Morphological, structural, microhardness and corrosion characterisations of electrodeposited Ni-Mo and Cr coatings. J. Braz. Chem. Soc., 21, 1968, 2010.

27. LENORT R., BESTA P. Logistics of scrapped electronics equipment disassembly, Acta Montanistica Slovaca, 4 (3), $268,2009$. 